response and survival compared with aminoglutethimide alone (R Murray, personal communication). Further studies are required, but we doubt whether combination endocrine treatment is likely to confer appreciable advantage in this disease.

${ }^{1}$ Mouridsen H, Palshof T, Patterson J, Battersby L. Tamoxifen in advanced breast cancer. Cancer Treat Rev 1978;5:131-41.

2 Smith IE, Harris AL, Morgan M, et al. Tamoxifen versus aminoglutethimide in the treatment of advanced breast cancer : a control randomised cross-over trial. Br Med f $1981 ; 283: 1432-4$.

${ }^{3}$ Powles TJ, Smith IE, Coombes RC. Endocrine therapy. In: Halman KE, ed. Treatment of cancer. London: Chapman and Hall, 1982:103-17.

${ }^{4}$ Mouridsen HT, Palshof T, Rose C. Therapeutic effect of tamoxifen alone versus tamoxifen in combination with gestagen and oestrogen in advanced breast cancer. Recent Results Cancer Res 1980;71:169-75.

${ }^{5}$ Powles TJ, Gordon C, Coombes RC. Clinical trial of multiple endocrine therapy for metastatic and locally advanced breast cancer with tamoxifenaminoglutethimide-danazol compared to tamoxifen used alone. Cancer Res 1982;42, suppl:3458-60s.

(Accepted 9 March 1983)

Breast Unit, Royal Marsden Hospital, London SW3 6JJ

IAN E SMITH, MD, MRCP, consultant medical oncologist ADRIAN L HARRIS, DPHIL, MRCP, lecturer in medicine ROBIN STUART-HARRIS, MRCP, lecturer in medicine

HUBERT T FORD, FRCR, consultant radiotherapist

JEAN-CLAUDE GAZET, MS, FRCS, consultant surgeon

HARVEY WHITE, MCH, FRCS, consultant surgeon

CLIVE L HARMER, FRCR, consultant radiotherapist

LORNA CARR, research secretary

J ALAN MCKINNA, FRCS, consultant surgeon

Princess Alexandra Hospital, Harlow, Essex

MICHAEL MORGAN, FRCS, consultant surgeon

\section{Clinically apparent rubella reinfection with a detectable rubella specific IgM response}

Subclinical reinfection with rubella may occur, particularly if seroconversion has been induced by rubella vaccine. ${ }^{1}$ Verified reinfections in which the patient has developed a rubelliform rash, however, have been reported infrequently. Traces of rubella specific IgM have been detected in reinfection in people with vaccine induced seroconversion after experimental challenge, ${ }^{2}$ but there is only one report of its detection in a reinfection after seroconversion due to natural infection. ${ }^{3}$ Indeed, the absence of detectable rubella specific IgM has become accepted as a characteristic of rubella reinfection. ${ }^{4}$

We report a case of confirmed, clinically apparent rubella reinfection in an immunocompromised patient with presumed previous natural infection and in whom a rubella specific IgM response was detected.

\section{Case report}

A 19 year old woman was diagnosed as having acute lymphoblastic leukaemia in April 1982. Remission induction chemotherapy with standard agents achieved a complete remission by the fourth week. Central nervous system prophylaxis (radiotherapy and intrathecal methotrexate) for four weeks was followed by maintenance treatment.

Seven days after beginning maintenance treatment (22 July) she presented feeling generally unwell with aching limbs, espisodes of shivering, and loose stools. She was feverish (39 C) and had conjunctival injection but no arthropathy or lymphadenopathy. Soon after admission a fine macular rash appeared over her arms and back. The white cell count was $3.4 \times 10^{9} / 1$ (neutrophils $20 \%$, lymphocytes $66 \%$, monocytes $14 \%$ ). The illness was clinically diagnosed as rubella and questioning disclosed contact with a child with a rubelliform rash three weeks previously. The patient gave a serologically unconfirmed history of rubella as a child and denied having been vaccinated against rubella. The illness resolved within three days.

Sera collected in April 1982, on the day of admission, and at later intervals were available (table). The six sera were evaluated for rubella specific antibodies by haemagglutination inhibition, radial haemolysis, and IgM capture radioimmunoassay. The results showed a haemagglutination inhibition titre of $100 \mathrm{IU}$ and a haemolytic zone of $12 \mathrm{~mm}$ for the serum collected in April. These values are accepted as indicative of previous primary rubella. Both of these assays showed a substantial, prompt rise in amount of detectable antibody at the onset of the illness. Antibody capture radioimmunoassay is a sensitive assay for rubella specific $\operatorname{IgM},{ }^{5}$ values exceeding 3.3 arbitrary units rarely being found without supporting evidence of recent rubella infection (personal observation). Rubella specific IgM was not detected in this patient's serum before her illness but a peak of 6.1 arbitrary units was found in the acute phase. The value declined over subsequent weeks. Rubella specific IgM was also detected by gel filtration and haemagglutination inhibition.

\section{Comment}

This patient's illness was clinically diagnosed as rubella and, though she was immunocompromised as a result of her chemotherapy and acute lymphoblastic leukaemia, it was symptomatically mild and of short duration. Even in immunocompromised patients, however, clinically apparent reinfections have been reported infrequently.

The other uncommon feature of the illness was the detection of rubella specific IgM using a sensitive quantitative assay. The detection of rubella specific IgM is established for reinfections in people with vaccine induced seroconversion but there is only one report of its occurrence in a reinfection in a person with natural seroconversion. ${ }^{3}$ In that report the patient also had a clinical illness and the diagnosis of a reinfection, rather than a primary infection, was based on the presence of rubella antibody detected by haemagglutination inhibition in a sample of serum taken before the illness. It is now accepted that haemagglutination inhibition titres may be due to residual non-specific inhibitors in the serum and not be indicative of rubella specific antibody. In our patient, preillness rubella specific antibody was detected by radial haemolysis in addition to haemagglutination inhibition.

Although our patient had disturbed immunological function, the results obtained do indicate that rubella specific IgM may be detectable in reinfections when previous seroconversion is due to natural infection. The amount of rubella specific IgM, however, was smaller than seen in primary infections.

Horstmann DM, Liebhaber H, Le Bouvier GL, Rosenberg DA, Halstead SB. Rubella: reinfection of vaccinated and naturally immune persons exposed in an epidemic. $N$ Engl f Med $1970 ; 283: 771-8$.

Balfour $\mathrm{HH} J r$ Groth $\mathrm{KE}$, Edelman $\mathrm{CK}$, Amren DP, Best JM, Banatvala JE. Rubella viraemia and antibody responses after rubella vaccination and reimmunisation. Lancet $1981 ; \mathrm{i}: 1078-80$.

${ }^{3}$ Strannegard Ö, Holm SE, Hermodsson S, Norrby R, Lycke E. Case of apparent reinfection with rubella. Lancet 1970;i :240-1.

1 Cradock-Watson JE, Ridehalgh MKS, Anderson MJ, Pattison JR. Out come of asymptomatic infection with rubella virus during pregnancy. f Hyg (Lond) $1981 ; 87: 147-54$

Mortimer PP, Tedder RS, Hambling MH, Shafi MS, Burkhardt F, Schilt U. Antibody capture radioimmunoassay for anti-rubella IgM. $\mathcal{F} H y g$ (Lond) $1981 ; 86: 139-53$.

(Accepted 2 March 1983)

King's College Hospital Medical School, London SE5 8RX

P MORGAN-CAPNER, MRCPATH, senior lecturer in medical microbiology C BURGESS, FIMLS, senior medical laboratory scientific officer R M IRELAND, MRCP, senior registrar in haematology

J C SHARP, MRCP, senior lecturer and consultant in haematology

Correspondence to: Dr P Morgan-Capner.

\begin{tabular}{|c|c|c|c|c|c|c|}
\hline & 14 April & $22 \mathrm{July}$ & 26 July & 2 August & 16 August & 29 October \\
\hline Radial haemolysis for rubella specific IgG (zone in $\mathrm{mm}$ ) & 12 & 15 & 17 & 17 & 17 & 17 \\
\hline Antibody capture radioimmunoassay for rubella specific $\operatorname{Ig} M$ (arbitrary units) & $1 \cdot 0$ & $6 \cdot 1$ & $5 \cdot 6$ & $5 \cdot 0$ & $4 \cdot 0$ & $2 \cdot 9$ \\
\hline Haemagglutination inhibition (IU) & 100 & 800 & 800 & 800 & 800 & 800 \\
\hline
\end{tabular}

